\title{
İlköğretim 8. Sınıf Matematik Dersinin Disiplinler Arası Yaklaşım İlkelerine Göre İşlenmesinin Öğrencilerin Matematik Başarısı Üzerindeki Etkisi*
}

\author{
Sevgi BUDAK COŞKUN** \\ Yıldız Teknik Üniversitesi, Sosyal Bilimler Enstitüsü, Beşiktaş Merkez Kampüsü Beşiktaş / İstanbul / Türkiye
}

\author{
Yrd. Doç. Dr. Sertel ALTUN***
}

Yıldız Teknik Üniversitesi, Eğitim Fakültesi, Eğitim Bilimleri Bölümü, Esenler / İstanbul / Türkiye

\section{Özet}

Bu çalışmanın amacı, ilköğretim 8. sınıf matematik dersinde disiplinler arası yaklaşım uygulamasının öğrencilerin matematik başarısı üzerindeki etkisini belirlemektir. Kontrol gruplu ön test-son test deneysel desen kullanılan çalışma grubu İstanbul'da bir ilköğretim okulunda 8. sınıfa devam eden 66 katılımcıdan oluşmaktadır. Veri toplamak amacıyla araştırmacılar tarafından geliştirilen matematik başarı testi kullanılmıştır. Disiplinler arası yaklaşım ilkelerine göre geliştirilen ders planları beş hafta boyunca uygulanmış ve uygulama sonucu elde edilen veriler SPSS paket programı kullanılarak kovaryans analizi ile yorumlanmıştır. Araştırma bulguları, disiplinler arası yaklaşımın matematik başarısını olumlu yönde etkilediğini göstermiştir.

Anahtar Kelimeler: Disiplinler arası yaklaşım; Matematik öğretimi; Matematik başarısı. 


\title{
The Effect of the Implementation of Interdisciplinary Approach in $8^{\text {th }}$ Grade Lessons of Mathematics on Mathematical Achievement of Students
}

\begin{abstract}
This study examines the effects of the implementation of interdisciplinary approach in $8^{\text {th }}$ grade mathematics lessons on mathematical achievement of students. The participants of the study in which pretest-post experimental model was used, consisted of 66 of $8^{\text {th }}$ grade students enrolled in a public school in İstanbul. To collect data, Mathematics Achievement Test developed by the researher was used. Lesson plans developed according to the principles of interdisciplinary approach were implemented during five weeks and analysis of covariance (ANCOVA) was computed by SPSS package for the analysis of data collected. The results indicate that interdisciplinary approach has positive effect on mathematical achievement.
\end{abstract}

Keywords: Interdisciplinary approach; teaching of mathematics,; Mathematical achievement.

\section{Extended Summary}

\section{Purpose}

This study briefly describes the principles of interdisciplinary lessons and process of developing an interdisciplinary math lessons. This study aims to determine the impact of lessons designed according to the principles of interdisciplinary approaches on $8^{\text {th }}$ grade students' mathematical achievement.

\section{Methods}

The research work group consists of 66 students who are 13-15 
years old and from middle socio-economic level attending Gazikent Primary School.

Pretest and posttest control group design was used in the study in order to determine whether or not there was a statistically significant difference in mathematical achievement in scores of the groups as a result of interdisciplinary teaching. Groups were selected randomly.

Lessons designed consist of the mathematical topics as fractals, scientific representations, graphics creations, geometry and the four arithmetical operations. Lessons developed according to the principles of interdisciplinary approach were implemented to the experimental group during five weeks of the study.

Mathematical Achievement Test developed by the researchers was applied twice, before and after the implementation. Instrument's validity and reliability analyses were done. Analysis of covariance (ANCOVA) was computed by SPSS package for the analysis of data collected.

\section{Results}

The result of the study indicates that interdisciplinary approach has a positive effect on mathematical achievement score, compared to traditional approach. Mathematical achievement level of experimental group is higher than the control group's level.

\section{Discussion}

Interdisciplinary approach gives a chance to students to become 
active in their learning, see the different viewpoints, relate the topics, analyse the problem and solve it. All of them may take students' interests and increase their motivation to the lesson and learning. By this way, the achievement may improve.

Suggestions can be developed for teachers and researchers. For example, a limitation in this study is that the application was only done five weeks at $8^{\text {th }}$ grade level. The study could be applied to other levels for al long time. As a suggestion for teachers, if a teacher wants to increase her students mathmetical achievement score, she should implement interdisciplinary approach in her lessons.

\section{Conclusion}

The study provides examples, strategies and principles of successful interdisciplinary approach used in $8^{\text {th }}$ grade mathematics classroom. The significance of this study is that it provides data to support the importance of using interdisciplinary approach in lessons.

\section{Giriş}

Değişen dünya düzeninde sosyo-ekonomik gelişmelerle birlikte bilgiye verilen önem ve bilgi üretimi hızla artmaktadır. Bilgi üretimindeki hızlı artış, toplumlarda ve bu toplumların yetiştirdiği bireylerde değişime neden olmaktadır. Sadece var olan eski bilgilerle çağa ayak uydurabilmek gün geçtikçe zorlaşmakta ve kişinin var olan tüm bilgileri ezberlemesi imkânsız hale gelmektedir. Ayrıca, var olan bilgiler, yenisi üretildiği için hızla eskimektedir (Fer, 2009, s.25). Bu nedenle, artık okullardan beklenen en önemli görev; bilgiyi ezberleyen 
bireyler yetiştirmek yerine, bilgiye nasıl ulaşacağını öğrenen, yaratıcı, üretici, problem çözebilen, bireyler yetiştirmektir (Aybek, 2006). Okullardan beklenen bu görevin gerçekleştirilmesi de öğretim programlarında ihtiyaçlara cevap verecek düzenlemeler yapılarak sağlanabilir. Düzenlemeler yapılan öğretim tasarımlarında, bu becerileri kazandırabilmek için geleneksel yaklaşımdan farklı yaklaşımlara odaklanılmalıdır. Bu noktada, yapılandırmacı yaklaşım, öğrencinin kendi öğrenmesinden sorumlu olduğu, kendi bilgisini yapılandırdığı ortamlar sunan bir yaklaşımdır (Marlowe ve Page, 1998; Woolfolk, 2004). $\mathrm{Bu}$ yaklaşım ile uyumlu tasarımlardan biri de, öğrenci merkezli tasarımlar içinde yer alan, farklı disiplinlerin bilgi ve becerilerine dayanarak problem çözme sürecine önem veren disiplinler arası yaklaşım tercih edilebilir. Disiplinler arası yaklaşım, disiplinler arasında bağlantılar kurmayı sağlayarak bir konunun farklı disiplinlerin bakış açısından incelenmesini sağlamaktadır (Yıldırım, 1996). Disiplinler arası yaklaşım ile problem çözerken bir konu, farklı disiplinlerin analizi ile işlenmekte ve onların becerisi 1şığında değerlendirilmekte, böylece birey kendisi için gerekli bilgiye kendisi ulaşabilmektedir. Bu doğrultuda, farklı bakış açılarından bakabilme yeteneğini gerektiren disiplinler arası yaklaşım, bireyin bilgiye ulaşma ve bilgi üretme sürecini olumlu yönde geliştirebilmektedir. "Etkili öğrenme yaşantılarını organize edebilmek için programın parçaları arasında yatay ilişki bulunmalıdır" (Tyler, 1969, s.84) görüşünden yola çıkarak; sadece tek bir disiplini içermeyen günümüz sorunlarının çözümleri için, disiplinlerin birleştirilerek etkileşimli öğrenme ortamlarının oluşturulduğu disiplinler arası yaklaşımın kullanılması gerekmektedir. Yapılan bazı ça- 
lışmalarda da, disiplinler arası yaklaşımın var olan bilgiyi yorumlayabilme, çıkarımda bulunabilme, analitik düşünebilme gibi temel becerilerin geliştirilmesine katkı sağladığı belirlenmiştir (Drake ve Burns, 2004; Mathison ve Freeman, 1997). Bu tür üst düzey zihinsel becerileri edinen birey var olan bilgiyi ezberlemek yerine ilişkiler kurarak, analiz ve sentez yeteneklerini kullanarak kendisi için gerekli ve geçerli bilgiye kendisi ulaşabilmektedir. Bu bağlamda, öğretim programları, disiplinler arası yaklaşım ile öğrencilerin bilgiyi ezberlemeleri yerine bilgiye ulaşmalarını sağlayabilir.

Diğer yandan, bireyin günümüz ihtiyaçlarını karşılayarak yaşamda başarılı olabilmesi için okulda edindiği bilgileri hayata taşıması gerekmektedir. Bu durum ise, farklı derslerde öğrenilen bilgiler arasındaki ilişkinin kurulmasıyla mümkün olabilmektedir. Çünkü hayatta karşılaşılan problemler, birbirinden kopuk değildir ve çözümleri birden çok disiplinin bilgisini gerektirmektedir. Bu nedenle, okullardaki öğretim programlarının düzenlenmesinde disiplinler arası yaklaşımın benimsenmesi önemli görülmektedir.

Türk eğitim sisteminde yeniden yapılandırma ile düzenlenmesi öngörülen bir başka konu da matematik öğretimi ve matematik disiplininde kazandırılması gereken becerilerdir. Geleneksel programlarda matematik dört işlem becerisi gerektiren bir disiplin olarak görülmekteydi. Günümüz programlarında ise, matematik öğretimi problem çözme, eleştirel düşünme ve ilişki kurma becerilerini gerekli kılmaktadır (MEB, 2005). Bu nedenle okullardaki matematik öğretiminin, söz konusu becerilerin geliştirilmesini sağlayacak şekilde düzenlen- 
mesi öngörülmektedir (Baykul, 2004). Bu bağlamda, ilişki kurmayı temel alan disiplinler arası yaklaşıma uygun konulara ağırlık verilmesi istenilen kazanımlara ulaşmada önemli rol oynamaktadır. Disiplinler arası yaklaşım ile hazırlanan öğrenme yaşantıları genellikle bir tema ya da problem merkezli olmasına ve takım çalışmasını içermesine rağmen, hazırlama süreci, belirlenen tasarımlar ve aşamaları ise farkl11ık göstermektedir. Yıldırım (1996), disiplinler arası yaklaşım kullanılarak hazırlanan öğretim tasarımlarında öğrencilerin var olan ve gelecekte olabilecek beceri ve ihtiyaçlarının dikkate alınması gerektiğini vurgulamaktadır çünkü bunlar diğer yaklaşımlara olduğu gibi disiplinler arası yaklaşıma da temel teşkil etmektedir. Disiplinler arası yaklaşım ilkelerine uygun tasarım hazırlama süreçlerine bakıldığında genel, evrensel bir süreç bulunmadığı görülmektedir. "Hangi model en iyisidir" sorusuna nasıl bir program oluşturulacağını belirleyen eğitim felsefesi 1şı̆̆ında cevap bulunabilmektedir. Disiplinler arası yaklaşıma uygun program hazırlama sürecinde belirlenecek tüm basamaklar eğitim politikasına ve özel durumlara, isteklere bağlı olabilmektedir. Takip edilecek prosedür aynı zamanda birleştirme, bütünleştirme derecesine ve seçilen entegre modeline bağlı olarak değişim gösterebilmektedir. Ancak program modeli ve eğitimde kazanılan deneyimler, bazı geniş prensiplerin ve genel hareket çizgilerinin belirlenmesine olanak sağlayabilmektedir (Mathison ve Freeman, 1997). Bu çalışmada, disiplinler arası yaklaşımın ilkelerine göre tasarım hazırlanırken Jacobs'un yedi basamaklı yaklaşımı ile Patricia ve Kellough'un yedi basamaklı yaklaşımı göz önüne alınmıştır. Genel itibariyle iki yaklaşımın birbirine benzer olması ve birbirinin eksikliklerini tamamlaması 
açısından bu iki yaklaşım seçilmiştir. Tasarım geliştirme basamağında ihtiyaç analizi, planlama, geliştirme, uygulama ve değerlendirme ilkelerine göre tasarlanan disiplinler arası yaklaşım tasarım modeli belirlenmiştir.

Bireylerin günlük yaşamla ilişki kurmasını ve günlük yaşam problemlerine çözüm üretmesini sağlayacak matematik öğretimi ise disiplinler arası yaklaşımı göz önüne alan öğretim tasarımları ile mümkündür. Çünkü disiplinler arası yaklaşım, günlük hayatta karşılaşılan problemleri çözerken matematik dersinde öğrenilen bilgi ve becerilerin kullanılmasına yardımcı olmaktadır (Leahey, 1999). Matematiksel bilgi ve becerinin, bireyin günlük yaşamda karşılaştığı problemlerdeki sebep-sonuç ilişkilerini açıklamasına ve çözüm yolu üretmesine yardımcı olacak becerileri geliştirdiği vurgulanmaktadır. Çünkü matematik bir bilim dalı olmasının yanında yaşanılan dünyayı anlamlandırmayı da sağlayan bir disiplindir (Golley, 1997). Bu nedenle, bireylerin günlük yaşamdaki sorunlarla daha etkili bir şekilde baş edebilmesi için matematiksel bilgi ve becerilere sahip olması gerekmektedir. Kander (2003) yaptığı çalışmada, disiplinler arası yaklaşıma göre düzenlenen öğretime katılan ve mezun olan öğrencilerin matematik ve fen konularını içeren günlük yaşamdaki problemleri rahatlıkla çözdüklerini ve üst düzey düşünmeyi gerçekleştirdiklerini tespit etmiştir. Konu ile ilgili yapılan başka bir çalışmada, disiplinler arası yaklaşıma göre ders alan öğrencilerin derse katılım ve ilişkili (bağlantılı) düşünme becerilerinin geleneksel yöntemle ders alan öğrencilere göre daha yüksek olduğu (Courtney, 2006) ortaya çıkmıştır. 
Sullivan (2000) yaptığı çalışmada disiplinler arası yaklaşımın öğrencilerin akademik başarısını olumlu yönde etkilediğini belirtmiştir. Disiplinler arası yaklaşım ilkelerine göre düzenlenen tasarımların öğrencilerin matematik başarısı, eleştirel düşünme eğilimi, motivasyonu, derse katılımı gibi değişkenler üzerinde olumlu etkisinin olduğu ortaya konmuştur (Lawrance, 1993; Vidaurry, 1996; Sullivan, 2000; Guercio, 2003; White ve Carpenter, 2008).

Varolan alan yazın ışı̆̆ında bu araştırmada da, disiplinler arası yaklaşımın matematik başarısına ne derece etki ettiğini belirlemek amacıyla çalışmalar yürütülmüştür. Disiplinler arası yaklaşımın uygulanması hem öğretim programının geliştirilmesinde hem de öğrenci öğrenmelerinin yordanmasında, eğitim bilimlerine önemli katkı sağlayacaktır. $\mathrm{Bu}$ anlamda, araştırma bulgularının aşağıda belirtilen ilgililere faydalı olabileceği düşünülmektedir:

- Öğretmenlere: Öğrencilerinin matematik başarısını arttırmak ve disiplinler arası yaklaşımı uygulamak isteyen matematik öğretmenlerine katkı sağlaması umulmaktadır. Bunun yanı s1ra, branşı matematik olmasa da derslerinde disiplinler arası yaklaşımı kullanmak isteyen öğretmenlere yol gösterici olacağ düşünülmektedir.

- Tasarımcılara: Program geliştirme çalışmalarını yürüten Talim Terbiye Kurulu Başkanlığı'na ve tasarımcılara, önerdikleri disiplinler arası yaklaşımın etkililiğinin belirlenmesi konusunda geri dönüt niteliğinde katkı sağlayacağı umulmaktadır.

- Araştırmacılara: Ülkemizde “disiplinler arası yaklaşımın ma- 
tematik başarısına etkisi”" adına yapılan çalışmaların az olması, olan çalışmaların da çoğunun betimsel araştırmalar olması nedeniyle deneysel bir araştırma olan bu çalışmanın bulgularının, bu konuda çalışmak isteyen araştırmacılara yol gösterici olacağı düşünülmektedir.

Bu katkılar düşünülerek araştırmada "İlköğretim 8. sınıf matematik derslerinin disiplinler arası yaklaşım ilkelerine göre işlenmesinin öğrencilerin matematik başarısına etkisi nedir?” problemine cevap aranmıştır.

\section{Yöntem}

\section{Araştırma Modeli}

Araştırmada, yapay koşullar altında ve araştırmacının kontrolünde geliştirilen disiplinler arası yaklaşıma dayalı öğretim tasarımının deney grubundaki öğrencilerin matematik başarısına etkisi incelendiğinden deneme modeli kullanılmıştır. Disiplinler arası yaklaşımın matematik başarısına etkisine bakmak için "kontrol gruplu ön test-son test model" kullanılmıştır. Bu model, deney ve kontrol grubunun bulunduğu, iki gruba da deney öncesi ve sonrası ölçümler yapıldığg zaman kullanılmaktadır (Karasar, 2005, 97). Araştırma deseni Tablo 1 'de verilmiştir.

Tablo 1. Araştırma Deseni

\begin{tabular}{cccc}
\hline Grup & $\begin{array}{c}\text { Matematik } \\
\text { Başarı Testi } \\
\text { (MBT) }\end{array}$ & Denel İşlem & $\begin{array}{c}\text { Matematik } \\
\text { Başarı Testi } \\
\text { (MBT) }\end{array}$ \\
\hline $\begin{array}{l}\text { Deney } \\
\text { Grubu }\end{array}$ & MBT1 & $\begin{array}{c}\text { Disiplinler Arası Yaklaşıma } \\
\text { Göre Hazırlanmış } \\
\text { Tasarım Uygulaması }\end{array}$ & MBT2 \\
\hline Kontrol & MBT1 & Disiplinler Arası Yaklaşımın & MBT2 \\
\hline
\end{tabular}


Grubu
Dikkate Alınmadığı Tasarım

Uygulamas1

\section{Çalışma Grubu}

Araştırmanın çalışma grubunu 2008-2009 eğitim-öğretim y1lında İstanbul ili Gaziosmanpaşa ilçesinde öğrenim gören 66 8. sınıf öğrencisi oluşturmaktadır. Deney grubunu 16 erkek (\% 24), 17 kız (\% 26); kontrol grubunu ise 15 erkek (\% 23) ve 18 kız (\% 27) öğrenci oluşturmaktadır. Normal dağılım gösterdiği belirlenen grupların 7. sınıf ikinci dönem matematik başarı ortalamaları incelendiğinde, deney grubunun başarı ortalamasının 81.54, kontrol grubunun ise 75.89 olduğu görülmektedir. Araştırma öncesinde, deney ve kontrol grubu öğrencilerinin matematik başarı düzeyleri arasındaki bu farkın anlamlılığını belirlemek için bağımsız gruplar t-test yapılmış ve farkın istatistiksel olarak anlamlı olmadığı ortaya çıkmıştır $(\mathrm{t}=1.8 ; \mathrm{p}>.05) . \mathrm{Bu}$ nedenle, öğrencilerin matematik başarı düzeyleri bakımından benzer gruplarda yer aldıkları varsayılmıştır.

Öğrencilerin öğretmenleri ile yapılan görüşme sonucunda grupların orta sosyo-ekonomik düzeyde oldukları ve yaşlarının 13-15 arasında değiştiği belirlenmiştir. Deney ve kontrol grubundaki öğrenci sayısının eşit olması, cinsiyet dağılımı ve matematik başarı düzeyi ortalamalarının birbirine benzer olması grup denkliğinde ölçüt olarak alınmıştır. Bu değişkenlere göre deney ve kontrol grubunun belirlenmesi random yoluyla seçilmiştir.

\section{Veri Toplama Araçları}

\section{Matematik Başarı Testi}


Araştırmada, öğrencilerin matematik başarı puanlarını belirlemek için araştırmacılar tarafından geliştirilen ve 45 sorudan oluşan "Matematik Başarı Testi” kullanılmıştır.

Matematik başarı testi hazırlanırken MEB'in 8. sınıf matematik dersi kazanımları incelenmiş ve bu kazanımlar doğrultusunda ders kitapları ve test kitaplarından yararlanılarak, fraktallar, araştırmaya uygun soru sorma ve örneklem belirleme, histogram, çok büyük-çok küçük sayılar konusunda toplam 45 çoktan seçmeli soru hazırlanmıştır.

Hazırlanan başarı testinin kapsam geçerliliği için üç matematik öğretmeninin, testin görünüş geçerliği için ise yöntem bilim uzmanının görüşleri alınmıştır. Bu değerlendirme sonrasında 32 8. sınıf öğrencisi ile pilot uygulama yapılmış ve elde edilen değerler ile madde analizi yapılmıştır. Yapılan analizlerin sonuçlarına göre nokta çift serili korelasyon değeri .20'nin altında olan 4 soru testten çıkarılmış ve çıkarılan test maddelerinden sonra testteki soruların kapsam geçerliliğinin sağlanması için uzman görüşü alınmıştır. Bu maddelerin de testten çıkarılmasından sonra testte 41 madde kalmıştır.

Testinin güvenirlik çalışması için KR-20 değeri hesaplanmış ve bu değer .88 olarak bulunmuştur. Bu değerin .70 'den büyük olması testin güvenilir olduğu anlamına gelmektedir (Büyüköztürk, 2002). Öğrenciler ölçekten 0 ve 41 arasında puan almıştır. Öğrenciler ölçekten 0 ve 41 arasında puan almıştır.

\section{Denel İşlem}

Disiplinler arası yaklaşımı destekleyen öğretimin oluşturulma- 
sinda Roberts ve Kellough'un (2000) önerdiği öğretim basamakları takip edilmiştir. Yedi basamakta yapılan işlemler aşağıda açıklanmıştır.

a) Konunun Seçilmesi: Bu aşamada araştırmacılar, disiplinler arası yaklaşıma uygun konu isimlerini bu disiplinlerin öğretmenleri yardımı ile birlikte belirlemiştir. Disiplinler arası konuların belirlenmesinden önce ihtiyaçlar belirlenmeye çalışılmıştır. Bu amaçla araştırmacı, öğrencilerin özelliklerini, yeteneklerini, eğitim ihtiyaçlarını analiz etmek amacıyla uygulamadan bir hafta önce öğrencilere iki ders saati boyunca matematik konuları ve yapılacak olan uygulama hakkında bilgi vermiş ve onların görüşlerini almıştır. Öğrencilerin matematik öğretmenlerinden alınan bilgiye göre, disiplinler ayrı ayrı öğretildiğinden öğrenciler matematik konuları ile diğer dersler arasında ilişki kuramamakta, bu nedenle bir derste öğrendikleri bilgiyi farklı derslerde kullanamamaktadır. Bu nedenle matematikle ilgili bazı konuları neden öğrendiğini fark etmekte, öğrendiklerini günlük yaşamda uygulamakta zorlanmakta ve bir problemin farklı çözüm yollarını keşfetmekte sıkıntı duymaktadır. Bu bağlamda, araştırmacı tarafından öğrencilerin ihtiyaçlarını gidermede etkili olabileceği ve öğrencilerin ilgisini çekebileceği düşünülen, günlük yaşamla bağlantılı olan, disiplinler arası yaklaşıma uygun beş genel matematik konusu seçilmiştir. Belirlenen konuların diğer derslerle bağlantıları kurularak disiplinler arası yaklaşıma uygun, günlük yaşamla ilişkili konular oluşturulmuştur. Belirlenen konularda disiplinler arası ilişkilerin etkili bir şekilde kurulması için araştırmacıyla aynı okulda görev yapan matematik, fen ve teknoloji, sosyal bilgiler, Türkçe öğretmenlerinin fikirleri alınmıştır. 
Böylece, Türkçe, fen ve teknoloji, sosyal bilgiler, tarih, müzik, bilgisayar ve görsel sanatlar disiplinleri ile ilişkili olan disiplinler arası yaklaşıma dayalı matematik temelli beş konu belirlenmiştir. Bu konuların isimleri branş öğretmenlerinin önerileri ile "Turizm Rehberi Oldum", "Fraktal Oluşturuyorum", "Küresel Isınma”, "Bilim Adamı Oldum” ve "Her Gün Kaç Kalori Yakıyorum” olarak belirlenmiştir.

b) Konuların Gözden Geçirilmesi: Bu aşamada disiplinler arası yaklaşıma uygun olarak geliştirilen konuların hedefleri, içerikleri ve kavramlar net olarak belirlenmiştir. Millî Eğitim Bakanlığı'nın 8. sınıf matematik öğretim programının içeriği incelenmiş ve belirlenen konulara ilişkin kazanımlar belirlenmiştir. Bu kazanımlar 1şığında belirlenen her konu ile ilişkili olan diğer derslerin kazanımları da bu derslerin branş öğretmenleri ile birlikte belirlenmiştir. Disiplinler arası yaklaşıma uygun olarak geliştirilen konuları kapsam geçerliliğinin sağlanması için uzman kişilerden görüş alınmıştır.

c) Eğitim Kaynaklarının Belirlenmesi: Seçilen her konunun işlenmesine uygun kaynaklar belirlenmiştir. Disiplinler arası yaklaşıma uygun konulara ait öğretim materyalleri, internet ve kaynak kitaplar kullanılarak araştırmacı tarafından hazırlanmıştır.

d) Konuların Organize Edilmesi: Seçilen konuların işlenişinde takip edilecek yönergeler ve sorulacak olan önemli sorular branş öğretmenlerinin yardımıyla hazırlanmıştır.

e) Sınıf Ortamının Düzenlenmesi: Öğrencilerin 35-40 kişilik s1nıflarda öğrenim gördükleri tespit edildiğinden onların bu ortamda 6-7 
kişilik gruplarla çalışabilecekleri bir öğrenme ortamı yaratılması öngörülmüştür. Ayrıca, her hafta işleyişe başlamadan önce öğrencilerin ilgisini çekebileceği düşünülen ve konularla ilişkili olan çeşitli fotoğrafların sınıf duvarlarına ve tahtaya asılmasına karar verilmiştir.

f) Ünite Finali, Kapanış Etkinliğinin Belirlenmesi: Bu aşamada, çalışmasını bitiren grupların ne öğrendiklerini ve nasıl çalıştıklarını özetleyip diğer öğrencilerle paylaşmaları sağlanmıştır. Dolayısıyla, çalışma bitiminde grup sunumları yapılmış ve gruplardan sunumlarını yaptıkları resimler, yazdıkları şiirler ile destekleyerek sunmaları istenmiştir. İsteyen grupların poster ya da tanıtıcı bir broşür hazırlayarak çalışmalarını sunmalarına izin verilmiştir. Sunumunu yapan grup ça1ışmalarını tahtaya yapıştırarak sergilemiştir.

g)Değerlendirmenin Belirlenmesi: Disiplinler arası yaklaşım ilkelerine göre hazırlanan konuların değerlendirilmesinde süreç ve sonuç değerlendirme yapılmıştır. Bir sonraki konuda gerekli düzenlemelerin yapılması ve uygulamanın öğrencilerin duygu, düşünce, davranışları üzerindeki etkisini belirlemek için öğrencilerin ürünleri ile her konu sonunda onlardan alınan yansıtma yazıları değerlendirmede kullanılmıştır. Öğrencilerin yansıtma yazılarını aşağıdaki sorulara cevap verecek şekilde yazmaları istenmiştir:

$\checkmark$ Nelerden hoşlandıkları,

$\checkmark$ Neleri değiştirmek istedikleri,

$\checkmark$ Zorlandıkları noktalar,

$\checkmark$ Hangi disiplinlere ait bilgi ve becerileri kullandıkları,

$\checkmark$ Farklı beceriler kazanmalarına yardımcı olup olmadığı, 
$\checkmark$ Öğrendiklerini günlük hayata aktarmalarına yardımcı olup olmadiğ 1 ,

$\checkmark$ Olaya farklı bakış açılarından bakmalarına yardımcı olup olmadığ1.

Sonuç değerlendirmede, disiplinler arası yaklaşımın ilkelerine göre tasarlanan konuların öğrencilerin matematik başarısı üzerinde etkili olup olmadığı matematik başarı testi ile belirlenmiştir.

\section{Uygulanan Örnek Ders Plânı}

\section{a) Konu: Turizm Rehberi Oldum:}

“Turizm Rehberi Oldum” adlı konuda matematiğe ait temel kazanımlar olan dört işlem becerisi, bilinçli tüketim yapma ve problem çözme becerileri ile sosyal bilgilerdeki yaşadığımız yeri ve tarihini keşfedelim, İngilizce dersindeki yaşadığımız yerdeki yapıların isimleri konularına ait kazanımlar arasında ilişki kurularak disiplinler arası yaklaşım oluşturulmuştur. Bu konuda; sosyal bilgiler dersinde öğrencilerin bulundukları bölgedeki tarihi eserler, yöresel eşyalar incelenirken bu eserlere ait kavramların İngilizce karşılıklarının da aynı anda konuya entegre edilmesi; görsel sanatlar dersinde öğrenilen kompozisyon kuralları kullanılarak bir poster-broşür yapılması, yaşadıkları şehrin üç günlük hava tahmini, döviz kurlarının takibi mümkündür. $\mathrm{Bu}$ şekilde disiplinler arası ilişkiler kurulabilmesi nedeniyle bu konu seçilmiştir.

\section{b) Kazanımlar:}

Kazanımlar Tablo 2'de belirtilmiştir. 
Tablo 2. Derslere Göre Öğrenci Kazanımları

\begin{tabular}{|c|c|c|c|c|c|}
\hline Matematik & İngilizce & $\begin{array}{c}\text { Sosyal } \\
\text { Bilgiler }\end{array}$ & $\begin{array}{c}\text { Görsel } \\
\text { Sanatlar }\end{array}$ & Türkçe & $\begin{array}{l}\text { Yaşamsal } \\
\text { Beceriler }\end{array}$ \\
\hline $\begin{array}{l}\text { *Dört işlem } \\
\text { ve problem } \\
\text { çözme } \\
\text { becerisini } \\
\text { kullanır. } \\
\text { *Bütçe } \\
\text { hesabı } \\
\text { yapar. } \\
\text { *Verilen } \\
\text { seçenek- } \\
\text { lerden } \\
\text { bütçesine } \\
\text { en uygun } \\
\text { olanı belir- } \\
\text { ler. }\end{array}$ & $\begin{array}{l}\text { *Yaşadığı } \\
\text { şehirde } \\
\text { yer alan } \\
\text { tarihî } \\
\text { eserlerin } \\
\text { İngilizce } \\
\text { karşılığını } \\
\text { bilir. } \\
\text { *Yaptığı } \\
\text { planı } \\
\text { İngiliz- } \\
\text { ceye } \\
\text { çevirir. }\end{array}$ & $\begin{array}{l}\text { *Yaşadığı } \\
\text { şehrin tarihî } \\
\text { eserlerini } \\
\text { keşfeder. } \\
\text { *Yaşadıkları } \\
\text { şehirdeki } \\
\text { turistlik } \\
\text { yerleri keş- } \\
\text { feder. } \\
\text { *Yaşadıkları } \\
\text { şehre özgü } \\
\text { hediyelik } \\
\text { eşyaları be- } \\
\text { lirler. }\end{array}$ & $\begin{array}{l}\text { *Görsel } \\
\text { kompozis- } \\
\text { yon } \\
\text { kurallarına } \\
\text { uygun } \\
\text { olarak } \\
\text { tanıtım } \\
\text { posteri } \\
\text { hazırlar. }\end{array}$ & $\begin{array}{l}\text { *Dil } \\
\text { bilgisi } \\
\text { kuralla- } \\
\text { rına } \\
\text { uygun } \\
\text { plan ve } \\
\text { tanitım } \\
\text { yazıları } \\
\text { yazar. }\end{array}$ & $\begin{array}{l}\text { *Döviz } \\
\text { kurunu baz } \\
\text { alarak, veri- } \\
\text { len parayı } \\
\text { Türk para- } \\
\text { sına çevirir. } \\
\text { *Günlük } \\
\text { hava duru- } \\
\text { munu pla- } \\
\text { nına yansı- } \\
\text { tır. } \\
\text { *İş birliği } \\
\text { becerileri } \\
\text { geliştirir. }\end{array}$ \\
\hline
\end{tabular}

c) Malzemeler: İstanbul'da bulunan turizm eserlerine, otellere, lokantalara, ulaşım araçlarına ait istasyonlara ve bunlara ait fiyat listeleri, renkli kartonlar, makas, hesap makinesi, Türkçe-İngilizce sözlük.

d) Giriş: Öğrencilerin ilgisini çekmek için diğer ülkelerden mektup arkadaşlarının olup olmadığı sorulur. Var ise bir anılarını anlatmaları istenir. 
e) İşleyiş: Öğrencilere yurt dışında bir mektup arkadaşlarının olduğunu hayal etmeleri istenir. Arkadaşları 3 günlüğüne onları ziyaret edecektir ancak İstanbul'u bilmediği için onlardan yardım istemektedir ve sadece 600 \$'1 vardır. 5'er kişilik gruplar oluşturularak verilen yönerge dâhilinde mektup arkadaşlarına gezi rehberi hazırlayıp poster yapmaları istenir.

f) Değerlendirme: Çalışma bitiminde, öğrencilerden ne öğrendikleri, en çok nelerden hoşlandıkları, bu derste nelerin olmasını istedikleri sorularına yansıtma yazıları alınır. Otantik değerlendirme olarak öğretmenin sınıf içindeki gözlemleri, öğrencilerden alınan geri dönütler ve oluşturulan gezi rehberleri kullanılır.

\section{Pilot Uygulama}

Tasarımda eksik kalabilecek kısımların tamamlanması adına, uygulanacak olan tasarım, 8. sınıfta okuyan 6 öğrenci ile bir hafta öncesinden pilot uygulamaya tâbi tutulmuştur. Uygulama, sınıfın matematik dersi öğretmeni tarafından beş hafta boyunca yürütülmüştür. Pilot uygulamanın ders öğretmeni tarafından yürütülmesinin temel amacı, gerçek uygulamanın da ilgili ders öğretmeni tarafından uygulanacak olmasıdır. Böylece araştırmacı tarafından öğretmene verilen ders tasarım formunun uygulanabilirliliği test edilmiştir. Uygulama süresince öğrencilerden ve matematik öğretmeninden alınan dönütler ışığında gerekli düzenlemeler yapılmış, materyaller iyileştirilmeye çalışılmıştır.

\section{İşlem Basamakları}


Araştırmanın uygulanmasında aşağıdaki adımlar takip edilmiştir.

1) Tasarımın uygulamasına başlanmasından bir hafta önce, uygulamanın gerçekleşeceği deney grubu öğrencileri ile 2 saat boyunca sohbet edilmiş ve uygulama hakkında bilgi verilerek uygulamaya içtenlikle katılmaları için motive edilmeye çalıŞılmıştır.

2) Deney ve kontrol grubu öğrencilerine matematik başarı testi ön test olarak uygulanmıştır.

3) Uygulama sürecinde, öğretmene düşen görevin yanında dersin ve öğrenme çevresinin düzenlenmesi konusunda öğretmen bilgilendirilmiş, hazırlanan konular bir hafta önceden öğretmene araştırmacı tarafından verilmiştir. Farklı disiplinlerin ilişkisini içeren konulara ait kazanımlar ilgili öğretmenlerin görüşleri alınarak belirlenmiştir. Matematik öğretmeni tarafından gerçekleştirilen uygulamada öğrenciler gruplar şeklinde çalışarak bu konuları işlemiştir. Her konu sonunda gruplardan yaptıkları çalışmaları poster ya da broşür haline getirerek sözlü olarak sunmaları istenmiștir.

4) Deney grubu öğrencileri ders öğretmeni eşliğinde "fraktallar, araştırmaya uygun soru sorma ve örneklem belirleme, histogram, çok büyük-çok küçük sayılar” konularına ait, disiplinler arası yaklaşım ilkelerine uygun olarak hazırlanmış "Turizm Rehberi Oldum", "Fraktal Oluşturuyorum", "Küresel Isınma”, "Bilim Adamı Oldum” ve "Her Gün Kaç Kalori Yakıyorum" adlı konularla grup çalışması şeklinde derslerini işlemiştir. Kontrol grubundaki öğrencilere ise aynı matematik konuları 
diğer disiplinlerden bağımsız olarak anlatılmıştır. $\mathrm{Bu}$ grupta öğretmen düz anlatım, soru-cevap, test çözümü yöntem ve tekniklerini kullanmıştır.

5) Deney grubunda toplam uygulama 7 hafta (14 ders saati) sürmüştür. Her uygulamada araştırmacılar ve dersin matematik öğretmeni ile iş bölümüne gidilmiştir. Öğretmen konuları işlemiş ve sınıf yönetimini sağlamış, araştırmacı ise bir sonraki dersin etkili uygulanmasına yönelik gözlemde bulunmuş söz konusu gözlemi ders öğretmeni ile dersin sonunda paylaşmıştir.

6) Uygulama bitiminde deney ve kontrol grubuna matematik başarı testi son test olarak tekrar uygulanmıştır.

\section{Verilerin Çözümlenmesi}

Araştırmanın problemine cevap bulmak amacıyla kovaryans (ANCOVA) analiz yönteminden yararlanılmıştır. Araştırmada deney grupları ve kontrol grubu üzerinde elde edilen nicel veriler SPPS 13.5 (Social Sciences Statistical Package) paket programı ile çözümlenmiştir. Sonuçların yorumlanmasında anlamlılık düzeyi olarak .05 kabul edilmiştir.

\section{Bulgular}

Araştırmanın denencesi "disiplinler arası yaklaşımın ilkelerine göre öğrenim gören deney grubu ile matematik konularını diğer disiplinlerden bağımsız olarak işleyen kontrol grubu öğrencilerinin matematik ön test başarı puanları kontrol altına alındığında son test başarı 
puanları arasında anlamlı bir fark vardır" şeklinde ifade edilmiştir. Bu denenceyi test etmek amaciyla, kovaryans ve öncesinde kovaryans varsayımlarını sağlamak için Kolmogorov-Smirnov z testi grupların regresyon eşitliği ve Levene analizi yapılmış ve elde edilen değerler Tablo 3’te verilmiştir.

Tablo 3. Deney ve Kontrol Grubu Kovaryans Varsayımları

\begin{tabular}{ccccc}
\hline Gruplar & Matematik & Kolmogorov- & Grupların & Levene \\
& Başarı & Smirnov Testi & Regresyon & Testi \\
& Puanı & & &
\end{tabular}

\section{Eşitliği}

\begin{tabular}{llllll}
\hline Z & $\mathrm{p}$ & $\mathrm{F}$ & $\mathrm{p}$ & $\mathrm{F}$ & $\mathrm{p}$
\end{tabular}

\begin{tabular}{llllllll}
\hline Deney & Ön Test & .88 & .42 & 1,67 & 0,76 & 1,38 & .24
\end{tabular}

Grubu

Son Test $\quad .63 \quad .81$

\begin{tabular}{llll}
\hline Kontrol & Ön Test & .78 & .57 \\
Grubu & & & \\
\cline { 2 - 4 } & Son Test & .83 & .49
\end{tabular}

Tablo 3 incelendiğinde, gruplara ait toplanan verilerin normal dağılım sergileyip sergilemediklerini belirlemek için yapılan Kolmogorov-Smirnov z testinde, deney grubunun matematik başarı ön test $\left(\mathrm{Z}_{\text {öntest }}=.88 ; p>.05\right)$ ve son test sonuçlarına $\left(\mathrm{Z}_{\text {sontest }}=.63 ; p>.05\right)$ ait $\mathrm{z}$ değerlerinin istatistiksel olarak anlamlı olmadığg bulunmuştur. Kontrol grubunun matematik başarı öntest $\left(\mathrm{z}_{\text {öntest }}=.78 ; p>.05\right)$ ve son test $\left(\mathrm{z}_{\text {son- }}\right.$ test $=.83 ; p>.05)$ sonuçlarıyla bulunan $\mathrm{z}$ değerlerinin de istatistiksel olarak anlamlı olmadığı görülmektedir. Bu durumda, belirlenen z de- 
ğerleri için iki grubun da normal dağılım gösterdiği görülmüştür. Grupların ön test son test regresyon eşitliğini test etmek amacıyla yapılan $F$ testinde $F=1,67$ ve $p>.05$ çıkmıştır. $B u$ değer grupların ön test son test regresyon doğrularının eğimlerinin eşit olduğunu gösterir. Ayrıca, Levene test sonucuna göre bütün grupların varyans dağılımlarının eşit olduğu görülmektedir $(\mathrm{F}=1.38 ; \mathrm{p}>.05)$. Elde edilen değerlere göre, gruplar normal dağılım gösterdiğgi, regresyon eşitliğini sağladığını ve matematik başarı son test puanlarında varyansların homojenliği sağlandığı için kovaryans analizi yapılmıştır.

Bunun için öncelikle deney ve kontrol gruplarının matematik başarı ön ve son test puanlarına ait betimsel istatistik sonuçları incelenmiştir. Elde edilen değerler Tablo 4'te verilmiştir.

Tablo 4. Deney ve Kontrol Grubu Matematik Başarı Ön Test-Son Test Puan Ortalamaları ve Standart Sapma Değerleri

\begin{tabular}{lccccc}
\hline Gruplar & $\mathbf{N}$ & \multicolumn{2}{c}{ Ön Test } & \multicolumn{2}{c}{ Son Test } \\
\cline { 3 - 6 } & & $\overline{\mathbf{X}}$ & SS & $\overline{\mathbf{X}}$ & SS \\
\hline $\begin{array}{l}\text { Deney } \\
\text { Grubu }\end{array}$ & 33 & 23.81 & 5.43 & 29.42 & 4.10 \\
\hline $\begin{array}{l}\text { Kontrol } \\
\text { Grubu }\end{array}$ & 33 & 26.12 & 7.3 & 26.57 & 4.32 \\
\hline
\end{tabular}

Tablo 4 incelendiğinde, deney grubunun matematik başarı ön test ortalama puan değeri deney öncesi 23.81 iken, bu değerin uygulama sonrasında 29.42 olduğu görülmektedir. Kontrol grubunun matematik başarı ön test ortalama puan değeri ise 26.12 'den 26.57 'ye yükselmiş- 
tir. Grupların son test başarı puanları arasındaki belirlenen farklılığın anlamlı olup olmadığını belirlemek amacıyla ön testler kontrol altına alarak yapılan kovaryans sonuçları Tablo 5 'te verilmiştir.

Tablo 5. Grupların Kovaryans Analizi Sonuçları

\begin{tabular}{llllll}
\hline & $\begin{array}{l}\text { Kareler } \\
\text { Toplamı }\end{array}$ & sd & $\begin{array}{l}\text { Kareler } \\
\text { Ortalaması }\end{array}$ & F & P \\
\hline Grup & 177.30 & 1 & 177.30 & 11.64 & $.00^{*}$ \\
\hline Hata & 943.70 & 62 & 15.22 & & \\
\hline \multicolumn{2}{c}{$* 0.01$} & & &
\end{tabular}

Tablo 5 incelendiğinde, deney ve kontrol grubunun son test başarı puanları arasındaki farkın deney grubu lehine anlamlı olduğu sonucuna ulaşılmıştır $\left(\mathrm{F}_{(1-62)}=11.649 ; \mathrm{p}<.01\right)$. Elde edilen bu bulgu, disiplinler arası yaklaşımın matematik başarı puanlarına anlamlı bir etkisinin olduğunu göstermektedir. Bu nedenle, araştırmanın denencisi doğrulanarak, disiplinler arası yaklaşımın ilkelerine göre öğrenim gören deney grubu öğrencileri ile matematik konularını diğer disiplinlerden bağımsız olarak öğrenen kontrol grubu öğrencilerinin matematik başarılarında fark olduğu söylenebilir.

\section{Sonuç ve Tartışma}

Araştırma kapsamında "disiplinler arası yaklaşımın ilkelerine göre hazırlanmış öğretim uygulanan deney grubu ile matematik konularını diğer disiplinlerden bağımsız olarak öğrenen kontrol grubu öğrencilerinin matematik başarısı son test puanları arasında anlamlı bir fark vardır" denencesi ispatlanmıştır. Başka bir ifade ile disiplinler arası yaklaşımla ders gören öğrencilerin matematik başarısının, konu- 
ları diğer disiplinlerden bağımsız olarak görenlere göre anlamlı derecede farklılık gösterdiği ortaya çıkmıştır. Dolayısıyla eldeki araştırmada, öğrencilerin matematik başarısının artmasında farklı disiplinlerin bilgi ve becerilerini sentezleyerek problem çözmeyi sağlayan disiplinler arası yaklaşımın etkili olduğu sonucuna ulaşılmaktadır.

Araştırmada deney grubundaki öğrencilerin matematik dersinde daha başarılı olması disiplinler arası yaklaşımın başarıyı arttırmada etkili olmasına bağlanmıştır. Anılan bulgu, bu alanda Cordogan ve Stanciak (2000) tarafından yapılan ve disiplinler arası yaklaşım ile öğrencilerin başarılarının arttığı sonucuna ulaşılan araştırmayı da destekler niteliktedir.

Disiplinler arası yaklaşımla öğrenci merkezli farklı yöntemlerin uygulanmasının öğrencilerin matematik başarılarını olumlu yönde etkilediği söylenebilir. Öğrenciler kendi öğrenmelerinden sorumlu olmuşlar, grup çalışması gerek matematik tarihini araştırmışlar, gerekse kendilerini bir bilim adamı olarak düşünerek dünyayı aydınlatmışlardır. Araştırmalarda da farklı ögretim yöntem ve yaklaşımlarının matematik başarısında etkili olduğu gözlenmiştir (Işık, 2007). Bu bağlamda, öğrenciyi merkeze alan, öğrencinin var olan bilgilerini sorgulayıp kendi bilgisini yaparak, yaşayarak üretmesine firsat tanıyan öğrenci merkezli yöntemler önem kazanmıştır.

Vygotsky (1978), öğrenmede dilin önemli etkisi olduğunu ve bilginin sosyal etkileşmelerle geliştiğini öne sürmüştür. Ona göre öğrenmenin gerçekleşebilmesi ve geliştirilmesi için “yakınsal gelişim 
bölgesi (YGB)" etkilidir. Vygotsky'nin YGB'si çocukların sosyal etkileşim yardımıyla bilişsel bir gelişiminin sağlanıp bir sonraki bilişsel aşamaya geçildiğinden bahseder. Bu düşünce değerlendirildiğinde, eldeki araştırmanın uygulanması sırasında oluşturulan küçük gruplarda öğrencilere matematikteki soyut fikirlerini paylaşma, etkileşerek öğrenme firsatı verildiği ve böylece öğrencilerin matematikteki bir sonraki bilişsel seviyelerine ulaştığı söylenebilir. Ayrıca, disiplinler arası yaklaşımın desteklediği küçük gruplarda çalışan öğrencilerin birbirlerini doğru yönlendirerek akranlarından öğrenmelerini sağlamış, bu durum da başarılarını arttırmalarına fırsat vermiş olabilir. Bu bağlamda, grup etkileşimi sırasında doğru şekilde sağlanan yönlendirme ile başarının gelişebileceği yönündeki araştırma bulguları (Cazden, 1981 aktaran, Rains, Catherine, Robert, 2008) ile eldeki araştırmanın bulguları benzerlik göstermektedir. Şimşek (2009) yaptığı çalışmada bilim tarihinin öğretilmesinin ve tarihin günlük yaşamla bağdaştırılmasının öğrencilerin başarısını arttırdığı sonucuna ulaşmıştır. Ona göre, öğrenci, bilim tarihi ile önceki bilim insanlarının izledikleri yolları, nasıl plan yaptıklarını, nasıl düşündüklerini fark edebilecek ve böylece sorgulama becerisini geliştirebilecektir. Sözü edilen bu durum, disiplinler arası yaklaşımla matematik tarihinin öğretilmesinde de geçerli olabilir. Eldeki araştırmada, matematik kavramları ve ortaya çıkış tarihleri, nasıl bulundukları ve kimlerin bulduğu gibi noktalar matematik ile geçmiş arasında ilişkiler kurulmasını sağlayarak kavramların daha ilgi çekici ve akılda kalıcı olmasını sağlamış olabilir. Ayrıca, dokunulabilen somut materyallerin öğretilen soyut matematiksel kavramların daha iyi anlaşılmasını sağladığını belirten araştırmanın (Cass, Cates, Jackson, \& 
Smith, 2003) bulguları ile disiplinler arası etkinliklerde somut materyallerle çalışılmasına firsat veren eldeki araştırmanın bulguları tutarl1dır. Kısaca, disiplinler arası yaklaşımla uygulanan etkinliklerdeki materyallerin, öğrencilerin öğrenmeleri ve matematik başarıları için olumlu katkıyı sağladığı sonucuna ulaşılabilir.

Konuyla ilgili alan yazında yapılan araştırmalar incelendiğinde, eldeki araştırmanın sonuçlarını doğrudan destekleyen çalışmalar olduğu görülmektedir. Vidaurry (1996), deney ve kontrol desenli yürüttüğü araştırmasının sonucunda disiplinler arası öğretim yapılan sınıflarda akademik başarının olumlu yönde etkilendiğini belirlemiştir. Bir başka araştırmada, fen ve teknoloji, sosyal bilimler ve sağlık eğitiminin birleştirildiği ilköğretim öğretim programının özelliklerini inceleyen Chan (2005), disiplinler arası yaklaşımın öğrencilerin disiplinler arası ilişkileri daha iyi görmesini ve öğrenme yetilerini arttırdığını bulmuştur. Disiplinler arası yaklaşımın etkililiği adına başka bir araştırma da Kander (2003) tarafından yapılmıştır. Disiplinler arası yaklaşımla ders gören ve daha sonra mezun olan öğrencilerin matematik ve fen konularını içeren günlük yaşamdaki problemleri çözmede zorlanmadıkları ve farklı disiplinlerden bireylerle etkili iletişim kurabildikleri gözlenmiştir. Leahey’in (1999) yaptı̆̆ bir çalışmada, disiplinler arası yaklaşımın öğrencilerin akademik başarısı üzerinde geleneksel yaklaşıma kıyasla anlamlı bir biçimde daha etkili olduğu ortaya çıkmıştır. Yapılan bu çalışmaların bulguları, disiplinler arası yaklaşımın başarıyı olumlu yönde etkilediği konusunda eldeki araştırmanın sonuçlarını açıklar ve destekler niteliktedir. 
Alan yazında eldeki araştırma sonuçlarıyla benzer olmayan konu ile ilgili sonuçlar da görülmektedir. Drury (1994) tarafından yapılan deneysel çalışmada, disiplinler arası yaklaşımın başarı üzerinde etkili olmadığı sonucuna ulaşılmıştır. Deney ve kontrol gruplarında yer alan öğrencilerin Amerikan tarihi, edebiyat, vatandaşlık sınavlardan aldığ1 notlar karşılaştırıldığında, kontrol grubunun vatandaşlık sınavında daha başarılı olduğu belirlenmiş, ancak diğer sınavlarda deney ve kontrol grubunun başarıları puanları arasında fark olmadığı ortaya çıkmıştır. Ciabocchi (2006) yaptığı çalışmada, görüşme, tarama, gözlem ve istatistiksel analizler yaparak New York'ta üniversite birinci sınıfta uygulanan çekirdek disiplinler arası yaklaşımın öğrenme ve öğretmeye etkisini araştırmıştır. Araştırmanın bulgularına göre, öğrencilerin \% 57'si uygulanan tasarımın eleştirel düşünme eğilimlerini geliştirdiğini belirtmesine rağmen, disiplinler arası yaklaşımın öğrencilerin akademik başarısını olumlu şekilde etkilemediği belirlenmiştir.

İlgili alan yazın incelendiğinde disiplinler arası yaklaşımın başarı üzerine hem etkili olduğunu hem de olmadığını belirten çalışmalar bulunmaktadır. Eldeki araştırma ise, disiplinler arası yaklaşıma göre tasarlanan öğretimlerin başarı üzerinde olumlu etkiye sahip olduğunu ortaya koyan araştırmaları destekler niteliktedir.

Sonuç olarak eldeki araştırma ile disiplinler arası yaklaşımın öğrencilerin matematik başarısını olumlu yönde etkilediği söylenebilir. 


\section{Öneriler}

$\mathrm{Bu}$ araştırmanın sonuçları 1şığında, disiplinler arası yaklaşımı uygulamak isteyen öğretmenlere aşağıdaki öneriler sunulabilir:

1. Öğretmenlerin, disiplinler arası yaklaşımın tanıtılması için düzenlenen seminerlere, kurslara katılmaları ve eğitimdeki yeniliklerin öğretimlerine sağlayacağı olası faydaları belirlemeleri önerilebilir.

2. $\mathrm{Bu}$ araştırma 8. sınıf matematik dersine ait belirli konular üzerinde yapılmıştır. Bu nedenle, diğer 8. sınıf matematik konularında, farklı derslerde ve farklı öğrenim düzeyleri (üniversite, lise) ile farklı kademelerde (6., 7. sinıf gibi) de disiplinler arası yaklaşımının etkisi incelenebilir.

3. Disiplinler arası yaklaşımının başarı üzerine etkisinin yanı sıra matematiksel yeterlilik, problem çözme becerisi, karar verme ve eleştirel düşünme becerisi gibi farklı değişkenler üzerine etkisi araştırılabilir.

4. Disiplinler arası yaklaşım ile matematik dersi konularının nasıl işlenebileceğine yönelik ders materyalleri geliştirilip öğrenci başarıları üzerindeki etkileri incelenebilir.

5. Disiplinler arası yaklaşımın etkili bir şekilde uygulanması için gerekli ön şartların neler olduğu ve günümüz öğrencilerinin bu şartların ne kadarına sahip olduğu konusu incelenebilir.

\section{Kaynakça}

Aybek, B. (2006). Konu ve beceri temelli eleştirel düşünme öğretiminin öğretmen adaylarının eleştirel düşünme eğilimi ve düzeyine 
etkisi. Çukurova Üniversitesi Sosyal Bilimler Enstitüsü Dergisi, 16(7), 43-60.

Baykul, Y. (2004). Illkögretimde matematik ögretimi 1.-5. sinıflar için (7.baskı). Ankara: PegemA Yayıncılık.

Büyüköztürk, Ş. (2002). Sosyal bilimler için veri analizi el kitabı: Istatistik, araştırma deseni, SPSS uygulamalarl ve yorum. Ankara: PegemA Yayıncılık.

Cass, M., Cates, D., Jackson, C., ve Smith, M. (2003). Effects of manipulative instruction on solving area and perimeter problems by students with learning disabilities. Learning Disabilities: Research \& Practice, 18(2), 112-200.

Chan, M. T. (2005). Features of an integrated primary curriculum. International Conference On Education, Singapore. 12 Eylül 2008, http://libir1.ied.edu.hk/dspace/handle/2260.2/879?mode=full.

Ciabocchi, E. (2006). Impact of a new, interdisciplinary freshman course on teaching and learning at a small liberal arts college in New York. Yayınlanmamış doktora tezi, Columbia University Teachers College.

Courtney, T. M. (2006). Interdisciplinary instruction and student engagement; A case study of midwestern suburban high school. Yayınlanmamış doktora tezi, Northern Illinois University, DeKalb.

Drake, S. ve Burns, R. (2004). Meeting standards through integrated curriculum. Alexandria, Va: Association for Supervision and Curriculum Development.

Drury, A. D. S. (1994). Restructuring the school: An assessment of the effect of an interdisciplinary curriculum on students' achieve- 
ment. Degree of specialist in education. Central Michigan University.

Fer, S. (2009). Öğretim tasarımı. Ankara: AnıYayıncılık.

Golley, P. S. (1997). An investigations of teachers' perceptions and implemetations of interdisciplinary mathematics and science. Doktora tezi, Georgia State Universty.

Guercio, C. J. (2003). An interdisciplinary curriculum and its positive effect on student motivation in the classroom. Yayınlanmamış yüksek lisans tezi, Caldwell College.

Işık, K. D. (2007). Çoklu zeka kuramı destekli kubaşık öğrenme yönteminin ilkögrretim dördüncü sinıf öğrencilerinin matematik dersindeki akademik başarılarına ve kalıcılı̆̆a etkisi. Yayınlanmamış yüksek lisans tezi, Çukurova Üniversitesi Sosyal Bilimler Enstitüsü.

Kander, R. (2003). A successful experiment in curriculum integration; Integrated science and technology at James Madison University. IEEE Eloctronic Periodicals, 3, 1-5.

Karasar, N. (2005). Bilimsel araştırma yöntemi (14. bask1). Ankara: Nobel Yayın Dağıtım.

Lawrence, E. M. (1993). Interdisciplinary curriculum influences on students' achievement, teacher and administrator attitudes and teacher efficiency. Yayınlanmamış doktora tezi, Arizona State University.

Leahey, L. K. (1999). An interdisciplinary approach to integrated curriculum. Yüksek lisans tezi, Rowan University.

Marlowe, B. A. ve Page, M. L. (1998). Creating and sustaining the constructivist classroom. ABD: Corwin Press Inc. 
Mathison, S. ve Freeman, M. (1997). The logic of interdisciplinary studies. Annual Meeting of the American Educational Research Association, Chicago.

Milli Eğitim Bakanlığı (MEB). (2005). 13.ilköğretim matematik dersi 6-7. Sinıflar ögretim program ve kllavuzu. (Taslak basım). Ankara: Devlet Kitapları Müdürlüğü.

Rains, J. R., Catherine, A. K. ve Robert L. D. (2008). The evolution of the importance of multi sensory teaching techniques in elementary mathematics: Theory and practice. Ĕgitimde Kuram ve Uygulama Dergisi, 4, 239-252.

Roberts, L. P. ve Kellough, D. R. (2000). A guide for developing interdisciplinary thematic units (2.bask1). United States: Prentice-Hall.

Şimşek, C. L. (2009). Fen ve teknoloji dersi öğretim programları ve ders kitapları bilim tarihinden ne kadar ve nasıl yararlanıyor? İkögretim Online e-Dergi, 8(1), 129-145.

Sullivan, J. M. (2000). A study of the effect of an interdisciplinary study improvement program on the academic achievement and classroom behavior among tenth grade students. Yayınlanmamış doktora tezi, Universty of Massachusetts Lowell.

Tyler, R. W. (1969). Basic principles of curriculum and instruction. Chicago: University of Chicago Press.

Vidaurry, M. M. (1996). Comparative study of interdisciplinary curriculum and non-interdisciplinary curriculum classrooms: The difference and relationships in regarding Taas scores, reading yearly averages and students' attitudes. Yayınlanmamış doktora tezi, Texas A ve I University. 
Wood, F. R. (2006). The Relationship Between the Measured Changes in the Mathematics Scores of Eighth Grade New Jersey Students and the Implementation of a Standards-Based Mathematics Program. Yayınlanmamış doktora tezi, Widener University.

Vygotsky, L. S. (1978). Mind in society: The development of higher psychological processes. Cambridge, MA: Harvard University Press.

White, D. J. ve Carpenteri, J. P. (2008). Integrating mathematics into the introductory biology laboratory course. Pro Quest Science Journals, 8, 22-38.

Y1ldırım, A. (1996). Disiplinlerarası öğretim kavramı ve programlar açısından doğurduğu sonuçlar. Hacettepe Üniversitesi Eğitim Fakültesi Dergisi, 12, 89-94. 